2. Горошко Е.И. Интегративная модель свободного ассоциативного эксперимента. Харьков, Москва: PA-Каравелла, 2001. URL: http://www.textology.ru/razdel.aspx?ID=38 (дата обращения 25.10.2020)

3. Стернин И.А. Психолингвистика и концептология. Bonpocbl психолингвистики. Научный журнал теоретических и прикладных исследований. 2007. № 5. С. 33-40.

4. Atkinson R.C., Raugh M.R. An application of the mnemonic keyword method to the acquisition of Russian vocabulary. Journal of Experimental Psychology: Human Learning and Memory. 1975.

DOI https://doi.org/10.30525/978-9934-588-90-7-88

\title{
ПРИНЦИП ПРОФЕСІЙНОЇ МІЖКУЛЬТУРНОЇ СПРЯМОВАНОСТІ ПРИ НАВЧАННІ ЕSР
}

\section{Трофименко А. 0.}

кандидат педагогічних наук, дочент кафедри іноземних мов

Кам'янець-Подільський національний університет імені Івана Огієнка м. Кам'янеиь-Подільський, Хмельницька область, Украйна

В останні роки Україна, включившись в процес активного економічного співробітництва із Заходом, водночас встала на шлях реформування сфери освіти. В українських вузах стали виникати нові відділення і факультети, які готують фахівців з таких спеціальностей, як зв'язку з громадськістю, державне управління, міжнародні відносини, міжнародне право, політологія і т. д.

Вступ світового співтовариства в еру інформаційної цивілізації визначає необхідність подолання комунікативних бар'єрів, якими $\epsilon$, зокрема, іноземні мови, тому в теорії і практиці сучасної освіти іншомовна професійна компетентність розглядається як найважливіша якість фахівця.

Використання інтерактивного підходу в навчанні ESP студентів $є$ виправданим і забезпечує хороші результати на увазі того, що успішне взаємодія в складних інтерактивних ситуаціях професійного спілкування багато в чому визначається вмінням налагодити міжособистісні відносини і залежить від готовності до неупередженого сприйняття партнера, усвідомлення етапів ситуації, стратегій і тактик кооперативної взаємодії, їх мовних маркерів, від знання специфіки професійної 
культури партнерів, лексикону і тезауруса певного мовного середовища i, що не менш важливо, від вміння адекватно інтерпретувати комунікативну інтенцію партнера.

Основними методичними принципами в навчанні ESP в немовних BН3 є принцип професійної комунікативної спрямованості і принцип професійної міжкультурної спрямованості. Суть принципу професійної комунікативної спрямованості полягає в тому, що навчання повинно будуватися на залученні студентів в усну (говоріння, аудіювання) i письмову (читання, письмо) професійну комунікацію протягом усього курсу навчання дисципліні «Іноземна мова», яка є невід’ємною частиною загальної професійної підготовки фахівця. Реалізація цього принципу забезпечує інтеграцію дисципліни «Іноземна мова» в загальний курс професійної підготовки фахівця-нефілолога, використання досвіду, отриманого в курсі вивчення спеціальних дисциплін, залучення студентів до активної творчої діяльність 3 оволодіння іншомовним мовленням 3 орієнтацією на рішення комунікативних професійних завдань, які передбачають мимовільне запам'ятовування матеріалу (проблемні ситуації, рольові ігри, «круглий стіл» і т. п.), відбір лінгвістичного матеріалу, що відображає мовну сутність професійних висловлювань фахівця.

Відомий лінгвіст і соціолог Д. Греддол в своєму популярному дослідженні "English Next" на основі аналізу соціологічних, економічних, демографічних i геополітичних чинників прогнозує домінування англійської мови в світовій науці, економіці та освіті протягом ще дуже довгого часу. Крім того, він стверджує, що в найближчі 10-15 років англійська мова все рідше буде виступати як самостійний предмет і буде все частіше інтегруватися в програму з предметної дисципліни [2, с. 86]. Викладачам англійської мови, які не готові до такої перепідготовки, він передрікає перспективу залишитися в майбутньому без роботи [2, с. 15].

Таким чином, вирішення проблеми може сприяти введенням інтегрованого навчання мови і спеціальності в якості нової стратегії іншомовної професійної підготовки фахівця. Професійно-орієнтовані навчальні програми, центровані на мові, вже не відповідають сучасним вимогам іншомовної підготовки міжнародного фахівця. Звичайно, підготовка за програмами ESP не втратила своєї актуальності. На початковому етапі вузівської іншомовної освіти підхід ESP в поєднанні $з$ EAP (English for Academic Purposes) $\epsilon$ необхідною основою для формування базової іншомовної професійної комунікативної компетенції фахівця. Однак в центрі навчальної програми 3 мовної підготовки повинна бути саме спеціальна дисципліна, іноземна мова в контексті 
інтернаціоналізації повинен служити інструментом передачі предметного знання за фахом; а оцінці в інтегрованому курсі повинні піддаватися як знання іноземної мови, так і знання предметної дисципліни. Все це має на увазі активна взаємодія лінгвістичних i предметних кафедр.

В результаті проходження подібного курсу викладач іноземних мов немовного вузу повинен наблизитися до вирішення основного завдання інтегрованого навчання у вузі- розвинути у майбутнього фахівця продуктивні навички ефективного усного та письмового професійноорієнтованого спілкування, підготувати його до двосторонньої ефективної участі в професійному і / або академічному дискурсі в умовах полікультурного світу і тим самим відкрити для нього можливості розвитку міжнародної кар'єри.

\title{
Література:
}

1. Knight J. Five truths about internationalization. International Higher Education // Boston College Magazine. Fall 2012. № 69. URL: www.bc.edu/cihe

2. Graddol D. English Next (2006). British Council. URL: http://www.britishcouncil.org/learning-research-english-next.pdf

DOI https://doi.org/10.30525/978-9934-588-90-7-89

\section{LINGUISTIC AND INTERCULTURAL COMMUNICATION COMPETENCE OF UKRAINIAN SERVICEMEN}

\author{
Turmys O. V. \\ PhD (Philology), Associate Professor, \\ Associate Professor at the Department of Foreign Languages \\ Odesa Military Academy \\ Odesa, Ukraine
}

Modern circumstances and geopolitical scenarios require from the Ukrainian military personnel not only high-quality professional training for performing professional duties in the ranks of the domestic armed forces, but also represent the strategic challenge of developing linguistic competence and the implementation of cross-cultural communication with representatives of foreign armies and fleets. The problem of proper language training and intercultural communication of the military personnel of the Armed Forces of 